\title{
PENGARUH DIMENSI KUALITAS JASA PADA KEPUASAAN KONSUMEN PADA RESTORAN MAKANAN CEPAT SAJI
}

\author{
Elisabet Dita Septiari \\ Universitas Atma Jaya Yogyakarta \\ ditaseptiari@staff.uajy.ac.id
}

\begin{abstract}
This study was conducted to analyze the effect of service quality dimensions toward customer satisfaction. Not all of these dimensions have same impact toward customer satisfaction in different service companies. A quantitative method was employed in this research. The respondents were customers of fast food restaurant. This study successfully collected the data with purposive sampling and analyzed 110 samples using multiple regressions. There were two finding, the first all of the service quality dimensions simultantly impacted customer satisfaction. Second, only tangibles, reliability, and assurance have positive effect toward customer satisfaction. This study gives insight to marketer or manager in service companies to be aware with dimension of service quality dimensions. They must analyze which dimensions that have impact on their customer satisfaction.
\end{abstract}

Keywords: customer satisfaction, service quality, tangibles, reliability, assurance, empathy, responsiveness

\section{PENDAHULUAN}

Di tengah kompetisi sektor industri yang semakin ketat dalam memperebutkan konsumen, perusahaan dituntut untuk memiliki keunggulan bersaing agar dapat bertahan hidup. Hampir semua perusahaan menawarkan produk dan jasa kepada konsumen. Dulu, perusahaan manufaktur hanya bergantung pada produk fisik, namun kini juga dilengkapi dengan pemberian jasa sebagai salah satu strategi bersaing. Bahkan di beberapa negara maju, perekonomian lebih banyak didominasi oleh sektor jasa (Zeithaml et al., 2009). Oleh karena itu perusahaan penyedia jasa harus memiliki keunggulan bersaing untuk dapat mempertahankan kehidupan usahanya. Salah satu strategi untuk mempertahankan kehidupan usahanya adalah dengan memberikan kualitas yang baik.
Kualitas jasa merupakan faktor penting bagi perusahaan jasa untuk menghasilkan kepuasan konsumen. Kepuasan konsumen menjadi penting bagi pemasar karena konsumen merupakan sumber penghasilan yang menentukan mati hidupnya suatu usaha. Kualitas jasa harus dimulai dari kebutuhan konsumen yang berakhir dengan kepuasan konsumen serta persepsi positif terhadap kualitas jasa (Kotler et al, 2009). Suatu produk dikatakan berkualitas bagi konsumen jika yang mereka rasakan sama dengan yang mereka harapkan. Konsumen yang terpuaskan cenderung akan melakukan penggunaan atau pembelian kembali (Cronin et al, 2000).

Menurut Parasuraman et al. (1988) kualitas jasa sangat dipengaruhi oleh jasa yang diharapkan (expected service) dan jasa yang dipersepsikan (perceived service). Kualitas 
jasa merupakan perbandingan antara jasa yang dirasakan dengan jasa yang diharapkan. Ada lima dimensi yang digunakan konsumen dalam menilai kualitas produk jasa yaitu keandalan, tanggap, jaminan, empati, dan tangibles. Kualitas jasa dapat mempengaruhi niat pembelian ulang. Apabila konsumen merasakan kualitas jasa baik, maka mereka cenderung memiliki keinginan membeli kembali apabila membutuhkan. Sedangkan jika konsumen merasakan kualitas jasa yang buruk, maka mereka memiliki keinginan yang kurang menyenangkan seperti komplain, berpindah ke penyedia jasa lain, dan tidak menggunakan jasa tersebut kembali.

Pada literatur jasa, banyak hasil penelitian yang menunjukkan bahwa bahwa kualitas jasa yang dipersepsikan mempengaruhi kepuasan pelanggan dan loyalitas pelanggan (Pollack, 2009). Namun menurut Jamal dan Anastasiadou (2009), penelitian yang menguji pengaruh dimensi kualitas jasa pada kepuasaan pelanggan dan loyalitas pelanggan juga perlu dilakukan. Menurut Chowdary dan Prakash (2007), tingkat kepentingan dimensi kualitas jasa yang berpengaruh pada pelanggan berbeda tergantung jenis jasanya, sehingga tidak dapat digeneralisasi. Oleh karena itu peneliti tertarik untuk meneliti pengaruh dimensi kualitas jasa yang dipersepsikan pada kepuasan konsumen dengan obyek penelitian restoran makanan cepat saji. Adapun rumusan masalah penelitian ini adalah: apakah dimensi kualitas jasa memiliki pengaruh terhadap kepuasaan konsumen dan keinginan membeli kembali. Hasil dari penelitian ini diharapkan dapat berguna bagi marketer khususnya pemilik atau pengelola restoran dalam memahami dimensi kualitas jasa sehingga dapat melakukan aktivitas yang meningkatkan kepuasan konsumen dan keinginan konsumen untuk membeli kembali.

\section{REVIEW LITERATUR DAN HIPOTESIS}

\section{Kualitas Jasa yang Dipersepsikan}

Jasa memiliki empat karakteristik yang dapat dibedakan dengan barang (Kotler et al, 2009). Keempat karakteristik tersebut adalah:

1. Intangibility. Jasa tidak dapat dirasakan oleh panca indra sebelum dibeli.

2. Inseparability. Jasa diproduksi dan dikonsumsi secara bersama-sama.

3. Variability. Kualitas jasa sangat bervariasi, bergantung pada penyedia jasa, kapan, dimana, dan siapa yang menggunakan jasa tersebut.

4. Perishability. Jasa tidak dapat disimpan untuk penggunaan atau penjualan yang akan datang.

Kualitas jasa yang dipersepsikan oleh konsumen berasal dari perbandingan antara kinerja jasa (persepsi) menurut konsumen dan harapan konsumen mengenai jasa tersebut. Kualitas jasa yang dipersepsikan merupakan perbedaan antara persepsi konsumen dan harapan konsumen (Zeithaml et al, 2009). Apabila jasa yang dipersepsikan lebih rendah daripada jasa yang diharapkan maka konsumen akan merasa kecewa. Perusahaan jasa yang sukses tidak hanya mampu memuaskan konsumennya tetapi juga menggembirakan konsumen.

Parasuraman et al.

mengidentifikasikan lima dimensi kualitas jasa yaitu:

1. Tangibles. Dimensi ini dinilai dari keberadaan fasilitas fisik, peralatan, penampilan karyawan dan materi komunikasi. Tangibles menjadi representasi perusahaan jasa secara fisik atau gambaran (images) yang digunakan pelanggan untuk menilai kualitas jasa, umumnya pelanggan baru (Zeithaml et al., 2009). 
2. Reliability (keandalan), yaitu kemampuan untuk memberikan pelayanan yang sesuai dengan janji dan akurat. Hal ini menunjukkan bahwa perusahaan jasa memenuhi janjinya baik dalam penyampaian jasa, provisi jasa, penyelesaian masalah, harga, dan hasil dari jasa (Zeithaml et al., 2009).

3. Responsiveness (daya tanggap), yaitu kesediaan untuk membantu konsumen dan memberikan pelayanan cepat. Dimensi ini menekankan pada perhatian dan kecepatan dalam menghadapi permintaan, pertanyaan, komplain, dan permasalahan pelanggan (Zeithaml et al., 2009).

4. Assurance (jaminan), berkaitan dengan pengetahuan dan kesopanan karyawan, serta kemampuan karyawan untuk menumbuhkan rasa percaya dan yakin pada konsumennya. Dimensi ini penting terutama bagi kategori jasa yang dianggap lebih berisiko atau sulit dievaluasi hasilnya, misalnya bank, jasa kesehatan, dan asuransi. Rasa percaya pelanggan dapat melekat pada karyawan perusahaan maupun perusahaan jasa itu sendiri (Zeithaml et al., 2009).

5. Empathy (empati), perhatian secara individual yang diberikan perusahaan kepada konsumennya. Inti dari dimensi ini adalah perlakuan yang personal dan customized, dengan menganggap pelanggan sebagai suatu yang unik, memiliki kebutuhan yang harus dipahami (Zeithaml et al., 2009).

\section{Kepuasan Konsumen}

Menurut Kotler et al. (2009) kepuasan merefleksikan perasaan suka atau kecewa sebagai akibat dari membandingkan hasil dan ekspektasi. Jika kinerja dibawah ekspektasi maka konsumen akan merasa kecewa. Jika kinerja sama dengan ekspektasi maka konsumen akan merasa terpuaskan. Jika kinerja melebihi ekspektasi maka konsumen akan merasa senang. Menurut Boonlertvanich (2009), kepuasan dievaluasi berdasarkan kepuasan kumulatif yang terkait dengan produk atau layanan dan berbagai aspek dalam perusahaan dari waktu ke waktu. Menurut Hunt (dalam Boshoff dan Gray, 2004), kepuasan adalah suatu proses, tidak melekat pada produk, tetapi, berdasarkan persepsi individu mengenai atribut produk. Kepuasan bersifat istimewa dan, terbentuk dari interaksi antara interpretasi perseptual mengenai layanan dan ekspektasi konsumen dari layanan tersebut. Akibatnya, konsumen yang berbeda akan memiliki tingkat kepuasan yang berbeda-beda untuk sebuah pengalaman yang pada dasarnya sama.

\section{Pengaruh Dimensi Kualitas Jasa yang Dipersepsikan terhadap Kepuasan Konsumen}

Kualitas jasa dan kepuasan konsumen telah teruji secara empiris memiliki pengaruh positif pada banyak penelitian pemasaran (Bei dan Chiao, 2001). Hasil penelitian Jamal dan Anastasiadou (2009) dengan subjek penelitian nasabah perbankan di Perancis menunjukkan bahwa dimensi tangibles, reliability dan empati berpengaruh positif pada kepuasan konsumen. Hasil penelitian Boshoft dan Gray (2004) menunjukkan bahwa tangibles, empati dan assurance berpengaruh positif terhadap kepuasan konsumen dengan objek penelitian rumah sakit. Berdasarkan hasil penelitian Pollack (2009), kelima dimensi kualitas jasa berpengaruh positif pada kepuasan konsumen. Berdasarkan hasil studi empiris di atas nampak bahwa pengaruh dimensi kualitas jasa pada kepuasaan konsumen berbeda untuk jenis jasa yang berbeda.

Berdasarkan beberapa penelitian diatas, maka peneliti menyimpulkan bahwa dimensi kualitas jasa berpengaruh positif pada kepuasan konsumen. Oleh karena itu peneliti merumuskan hipotesis sebagai berikut:

$\begin{array}{llll}\mathrm{H}_{1}: & \begin{array}{l}\text { Tangibles berpengaruh positif pada } \\ \text { kepuasaan konsumen. }\end{array} \\ \mathrm{H}_{2}: & \begin{array}{l}\text { Reliability berpengaruh positif pada } \\ \text { kepuasaan konsumen. }\end{array} & & \\ & \end{array}$




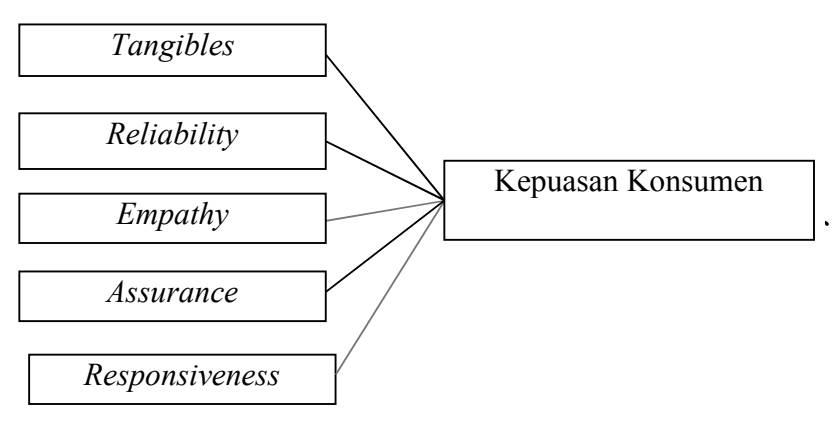

Gambar 1

Model Penelitian

\section{METODE PENELITIAN}

\section{Metode Pengumpulan Data}

Metode pengumpulan data menggunakan kuesioner. Kuesioner terdiri dari 25 item pertanyaan yang mengukur dimensi kualitas jasa dan kepuasan konsumen. Kuesioner dijawab dengan lima skala likert.

\section{Teknik Pengambilan Sampel}

Teknikpengambilan sampelmenggunakan purposive sampling, dengan persyaratan responden minimal tiga bulan terakhir makan di restoran cepat saji. Menurut Hair et al. (2010), Rasio minimal antara sampel dan item untuk mengukur suatu variabel adalah 5:1. Variabel penelitian ini adalah 7 sehingga minimal sampel sebesar 50.

\section{Instrumen Penelitian}

Penelitian ini terdiri dari tiga variabel yang akan diukur menggunakan instrumen kuesioner. Dimensi kualitas jasa diukur menggunakan kuesioner yang diadaptasikan dari Parasuraman et al. (1988) dan terdiri dari 23 item pertanyaan. Kuesioner kepuasaan konsumen diadaptasikan dari $\mathrm{Hu}$ et al. (2009) yang terdiri dari 2 item pertanyaan.

\section{Pengujian Instrumen}

Uji validitas dilakukan dengan menggunakan confirmatory factor analysis. Menurut Hair et al. (2010) faktor loading 0,5 atau lebih dianggap paling layak digunakan dalam menentukan nilai loading yang signifikan. Uji reliabilitas diukur menggunakan koefisien cronbach alpha. Nilai cronbach alpha 0,6 menunjukkan reliabilitas dapat diterima, (Hair et al, 2010). Sedangkan metode analisis yang digunakan untuk menguji hipotesis adalah regresi berganda. Ketepatan fungsi regresi dalam menafsirkan model dapat diukur dari nilai statistik t, nilai statistik F, koefisien determinasi, dan koefisien regresi (Hair et al, 2010).

\section{HASIL PENELITIAN DAN PEMBAHASAN}

\section{Karakteristik Sampel}

Sampel penelitian ini sebanyak 110 responden. Responden terbagi menjadi 44,5\% pria dan $55,5 \%$ wanita. Berdasarkan alasan memilih restoran cepat saji, $42 \%$ menyatakan bahwa makanan direstoran cepat saji enak, 30\% menyatarakan bahwa cepat dalam penyajian, sedangkan $28 \%$ menyatakan senang dengan suasana di restoran cepat saji.

\section{Uji Validitas dan Reliabilitas}

Berdasarkan tabel 1, hasil uji validitas menunjukkan bahwa semua variabel mengelompok pada faktor yang sesuai dengan variabelnya dengan faktor loading diatas 0,5.

Hasil uji reliabilitas nampak pada tabel 2. Berdasarkan tabel 2 tersebut, semua variabel memiliki nilai cronbach's alpha diatas 0,6 sehingga memenuhi uji reliabilitas. 
Tabel 1

Hasil Analisis Faktor

\begin{tabular}{|c|c|c|c|c|c|c|c|}
\hline & \multicolumn{7}{|c|}{ Komponen } \\
\hline & 1 & 2 & 3 & 4 & 5 & 6 & 7 \\
\hline t5 & & & & 0,842 & & & \\
\hline t4 & & & & 0,670 & & & \\
\hline $\mathrm{t} 3$ & & & & 0,781 & & & \\
\hline $\mathrm{t} 2$ & & & & 0,664 & & & \\
\hline $\mathrm{t} 1$ & & & & 0,695 & & & \\
\hline rs1 & & & & & 0,604 & & \\
\hline rs2 & & & & & 0,905 & & \\
\hline rs3 & & & & & 0,897 & & \\
\hline rs4 & & & & & 0,626 & & \\
\hline e5 & 0,583 & & & & & & \\
\hline e4 & 0,849 & & & & & & \\
\hline e3 & 0,835 & & & & & & \\
\hline e2 & 0,836 & & & & & & \\
\hline e1 & 0,766 & & & & & & \\
\hline $\mathrm{rl}$ & & & 0,889 & & & & \\
\hline $\mathrm{r} 2$ & & & 0,690 & & & & \\
\hline $\mathrm{r} 3$ & & & 0,720 & & & & \\
\hline $\mathrm{r} 4$ & & & 0,828 & & & & \\
\hline r5 & & & 0,769 & & & & \\
\hline a1 & & 0,924 & & & & & \\
\hline a2 & & 0,946 & & & & & \\
\hline a4 & & 0,926 & & & & & \\
\hline a3 & & 0,596 & & & & & \\
\hline $\mathrm{kk} 1$ & & & & & & & 0,653 \\
\hline $\mathrm{kk} 2$ & & & & & & & 0,868 \\
\hline repurchase & & & & & & 0,955 & \\
\hline repurchase & & & & & & 0,954 & \\
\hline & & & & & & & \\
\hline
\end{tabular}

Sumber: hasil olah data

Tabel 2

Hasil Uji Reliabilitas Penelitian

\begin{tabular}{|l|c|}
\hline \multicolumn{1}{|c|}{ Variabel } & Cronbach's alpha \\
\hline Tangibles & 0,794 \\
\hline Reliability & 0,787 \\
\hline Empathy & 0,866 \\
\hline Responsiveness & 0,857 \\
\hline Assurance & 0,919 \\
\hline Kepuasan konsumen & 0,701 \\
\hline Keinginan membeli kembali & 0,952 \\
\hline
\end{tabular}

Sumber: hasil olah data

\section{Pengujian Hipotesis}

Pengujian hipotesis dalam penelitian ini dilakukan secara simultan. Adjusted $\mathrm{R}^{2}$ menunjukkan bahwa 27,5\% dapat dijelaskan oleh dimensi-dimensi kualitas jasa, sedangkan sisanya dijelaskan oleh variabel lain. Berdasarkan hasil dari tabel 3 tidak semua hipotesis dapat terdukung. Hasil pengujian menunjukkan nilai F sebesar 9,262 dan nilai signifikansi sebesar 0,000 sehingga dapat disimpulkan bahwa semua variabel independen yaitu kelima dimensi dari kualitas pelayanan jasa secara simultan memiliki pengaruh yang signifikan terhadap kepuasan konsumen. Tabel 3 juga menunjukkan hasil uji t dari kelima dimensi jasa, hanya tiga dimensi yang berpengaruh pada kepuasaan konsumen yaitu tangibles, reliability, dan assurance. Sedangkan dimensi empathy, dan responsiveness tidak berpengaruh pada kepuasaan konsumen.

\section{Tabel 3}

\section{Hasil Pengujian Hipotesis}

\begin{tabular}{|c|c|c|c|c|c|c|}
\hline $\begin{array}{l}\text { Variabel } \\
\text { Independen }\end{array}$ & $\beta$ & $\mathrm{t}$ & $\operatorname{sig}$ & $\operatorname{Adj}^{2}$ & $\mathrm{~F}$ & sig \\
\hline Tangible & 0,178 & 2,104 & $\mathbf{0 , 0 3 8}$ & \multirow[t]{5}{*}{0,275} & \multirow[t]{5}{*}{9,262} & \multirow[t]{5}{*}{0,000} \\
\hline Responsiveness & 0,076 & 0,905 & 0,367 & & & \\
\hline Empathy & 0,035 & 0,388 & 0,699 & & & \\
\hline Reliable & 0,058 & 0,657 & 0,043 & & & \\
\hline Assurance & 0,520 & 6,049 & 0,000 & & & \\
\hline
\end{tabular}

Sumber: hasil olah data

Hipotesis pertama yang menyatakan bahwa tangibles atau bukti fisik memiliki pengaruh secara positif pada kepuasaan konsumen terdukung. Hasil penelitian ini konsisten alasan responden memilih restoran cepat saji salah satunya karena suasana restoran cepat saji yang menyenangkan. Hasil penelitian ini juga konsisten dengan hasil penelitian Jamal dan Anastasiadou (2009) dan Boshoft dan Gray (2004).

Hipotesis kedua yang menyatakan bahwa reliability (keandalan) berpengaruh positif pada 
kepuasaan konsumen terdukung. Keandalan menunjukkan kemampuan untuk memberikan pelayanan yang sesuai dengan janji dan akurat. Hal ini juga sesuai dengan alasan responden memilih restoran cepat saji karena pelayanannya cepat, ditambah pula harga dan bentuk menu sesuai dengan daftar yang tertera. Hasil penelitian ini juga konsisten dengan hasil penelitian Jamal dan Anastasiadou (2009) dan Pollack (2009).

Hipotesis ketiga yang menyatakan bahwa empati berpengaruh positif pada kepuasan konsumen tidak terdukung. Hal ini dikarenakan interaksi antara karyawan dengan konsumen tidak terlalu banyak sehingga konsumen tidak terlalu merasakan dimensi empati dari karyawan. Konsumen cenderung memesan menu dan membayar kemudian memilih tempat untuk memakan menu cepat saji, sehingga interaksi dengan karyawan tidak terlalu banyak.

Hipotesis keempat yang menyatakan bahwa assurance atau jaminan berpengaruh positif pada kepuasaan konsumen terdukung. Dimensi assurance menunjukkan bahwa karyawan mampu menumbuhkan rasa percaya dan yakin pada konsumennya mengenai perusahaan jasa. Hasil penelitian ini mendukung hasil penelitian Boshoft dan Gray (2004).

Hipotesis kelima yang menyatakan bahwa responsiveness berpengaruh positif pada kepuasaan konsumen tidak terdukung. Dimensi ini menekankan pada perhatian dan kecepatan dalam menghadapi permintaan, pertanyaan, komplain, dan permasalahan konsumen. Namun kecenderungannya pada restoran makanan cepat saji tidak banyak komplain dan masalah yang dialami konsumen.

\section{KESIMPULAN DAN SARAN}

\section{Kesimpulan}

Berdasarkan hasil analisis data terhadap pengujian hipotesis, maka dapat diambil kesimpulan bahwa kelima dimensi kualitas jasa berpengaruh secara simultan terhadap kepuasaan konsumen. Hasil penelitian secara parsial menunjukkan hanya dimensi bukti fisik, keandalan, dan jaminan yang berpengaruh pada kepuasaan konsumen untuk obyek penelitian restoran cepat saji. Hal ini mendukung pendapat Cronin et al. (2000) bahwa setiap jenis perusahaan jasa memiliki dimensi yang berbeda dalam memuaskan konsumennya.

\section{Saran}

Penelitian selanjutnya dapat variabelvariabel selain dimensi kualitas jasa dalammenguji faktor yang mempengaruhi variabel kepuasan konsumen. Selain itu dapat menggunakan objek penyedia jasa lainnya untuk membandingkan dimensi kualitas jasa yang berpengaruh.

\section{DAFTAR PUSTAKA}

Bei, L. T. dan Chiao, Y. C. 2001. "An Integrated Model for The Effect of Perceived Product, Perceived Service Quality, Perceived Price Fairness on Customer Satisfaction and Loyalty", Journal of Consumer Satisfaction, Dissatisfaction, and Complaining Behavior, Vol. 14, pp. 125-140.

Boonlertvanich, K. 2009. “A Conceptual Model for The Repurchase Intentions in The Automobile Service Industry: The Role of Switching Barriers in Satisfaction Repurchase Intentions Relationship", International Journal of Business Research, Vol. 9, No. 6, pp. 1-18.

Boshoff, C. dan Gray, B. 2004. "The Relationships between Service Quality, Customer Satisfaction and Buying Intentions in the Private Hospital Industry", South African Journal of Business Management, Vol. 3, No. 4, pp. 27-37.

Cronin, J., Brady, M. dan Hult, T. 2000. "Assessing the Effect of Quality, Value, 
and Customer Satisfaction on Customer Behavioral Intentions in Service Environments," Journal of retailing, Vol. 76, No. 2, pp. 193-218.

Hair, J. F., Black, W. C., Babin, B. J., Anderson, R. E. and Tatham, R. L. (2010), Multivariate Data Analysis, $7^{\text {th }}$ ed, Upper Saddle River, New Jersey: Pearson Education, Inc.

Hu, H. H., Kandampully, J. dan Juwaheer, T. D. 2009. "Relationships and Impacts of Service Quality, Perceived Value, Customer Satisfaction, and Image: An Empirical Study, ” The Service Industries Journal, Vol. 29, No. 2, pp. 111-125.

Jamal, A. dan Anastasiadou, K. 2009. "Investigating the Effect of Service Quality Dimensions and Expertise on Loyalty", European Journal of Marketing, Vol. 43, No. 3, pp. 398-420.

Kotler, P. dan Keller, K. L. 2009. Marketing Management, $13^{\text {th }}$ ed. Upper Saddle River, New Jersey: Pearson Education, Inc.

Lee, Y. dan Hing, N. 1995. "Measuring Quality in Restaurant Operations: An Application of the SERVQUAL Instrument", International Journal Hospitality Management, Vol. 14, No. 3/4, pp. 293 310.
Louis, A., Tucci, L. A. dan Talaga, J. A. 2000. "Determinants of Consumer Perceptions of Service Quality in Restaurants", Journal of Food Products Marketing, Vol. 6, No. 2, pp. 3-13.

Parasuraman, A., Berry, L. L. dan Zeithaml, V. 1990. "Guidelines for Conducting Service Quality Research," Marketing Research.

Parasuraman, A., Zeithaml, V. dan Berry L. L. 1988. "SERVQUAL: A MultipleItem Scale for Measuring Consumer Perception of Service Quality", Journal of Retailing, Vol. 64, No. 1, pp. 12-40.

Pollack, B. L. 2009. "Linking The Hierarchical Service Quality Model to Customer Satisfaction and Loyalty", Journal of Services Marketing, Vol. 23, No. 1, pp. 42-50.

Zeithaml, V., Berry, L. L. dan Parasuraman, A. 1996. "The Behavioral Consequences of Service Quality," Journal of Marketing, Vol. 60 (April), pp. 31-46.

Zeithaml, V.; Bitner, M. J. and Gremler, D. D. (2009), "Services Marketing: Integrating Customer Focus Across the Firm," $5^{\text {th }}$ ed. New York: McGraw-Hill Companies, Inc. 